\title{
Effect of Mulching and Pre-Sowing Seed Treatment with Agro Chemicals on the Growth and Yield of Summer Sesame (Sesamum indicum L.) Under Limited Water Resources
}

\author{
Gari Prameela ${ }^{1 *}$, Tanuj Kumar Mandal ${ }^{1}$, Sagar Maitra ${ }^{1}$ and Pushpalatha G. ${ }^{2}$ \\ ${ }^{1}$ Department of Agronomy, M.S. Swaminathan School of Agriculture, Centurion University of Technology and Management, \\ Paralakhemundi-761 211, India \\ ${ }^{2}$ Department of Crop Physiology \& Bio-Technology, M. S. Swaminathan School of Agriculture, Centurion University of Technology \\ and Management, Paralakhemundi-761 211, India
}

*Corresponding author: prammi.rockz18@gmail.com (ORCID ID: 0000-0001-8447-6257)

Paper No. 795

Received: 11-04-2019

Revised: 19-07-2019

Accepted: 20-08-2019

\begin{abstract}
Moisture stress is a limiting factor to achieve potential yield of summer sesame (Sesamum indicum L.) under limited water resources and mulching is one of the suitable measures to mitigate the problem. Further, pre-sowing soaking of seeds with chemicals can facilitate growth, physiological and metabolic activities and thus enhance crop productivity. An experiment was conducted at Bagusala Farm of MS Swaminathan School of Agriculture, Centurion University of Technology and Management, Paralakhemundi (233' $\mathrm{N}$ latitude, $87^{\circ} 42^{\prime}$ E longitude) during summer season of 2018 to study the effect of mulching and pre-sowing seed treatment with agro chemicals on growth and productivity of summer sesame. The experimental soil was sandy loam in texture with a $\mathrm{pH}$ of $6.1,0.73 \%$ organic carbon and 230, 32.1 and $346 \mathrm{~kg} \mathrm{ha}^{-1}$ of available N, P and K, respectively. The experiment was laid out in Split Plot Design (SPD), with two factors, namely, mulching (main plot) and seed soaking with agro-chemicals (sub-plot). In main plot three treatments of mulching were taken, namely, $\mathrm{M}_{0^{\prime}}$ no mulching, $\mathrm{M}_{1}$, paddy straw mulching and $\mathrm{M}_{2^{\prime}}$ plastic mulching, however, four seed soaking treatments, viz., $\mathrm{P}_{1}$, water soaked, $\mathrm{P}_{2}, 200$ ppm potassium chloride $(\mathrm{KCL}), \mathrm{P}_{3^{\prime}} 400$ ppm potassium dihydrogen phosphate $\left(\mathrm{KH}_{2} \mathrm{PO}_{4}\right)$ and $\mathrm{P}_{4^{\prime}} 400$ ppm disodium hydrogen phosphate $\left(\mathrm{Na}_{2} \mathrm{HPO}_{4}\right)$ were considered in sub-plot. Thus 12 treatments combinations were replicated thrice in $4 \mathrm{~m} \times 3 \mathrm{~m}$ plots. Sesame variety 'Gauri' performed well with plastic mulching as it recorded significantly better growth and higher yield than paddy straw mulching and no mulching. Among seed soaking treatments, it was noted that pre-sowing seed soaking with either of 400 ppm of $\mathrm{Na}_{2} \mathrm{HPO}_{4}$ or 400 ppm of $\mathrm{KH}_{2} \mathrm{PO}_{4}$ exhibited superiority to other treatments to obtain higher productivity. Moreover, plastic mulching and seed soaking with either of $\mathrm{Na}_{2} \mathrm{HPO}_{4}$ or $\mathrm{KH}_{2} \mathrm{PO}_{4}$ combination resulted in higher net return and benefit: cost ratio.

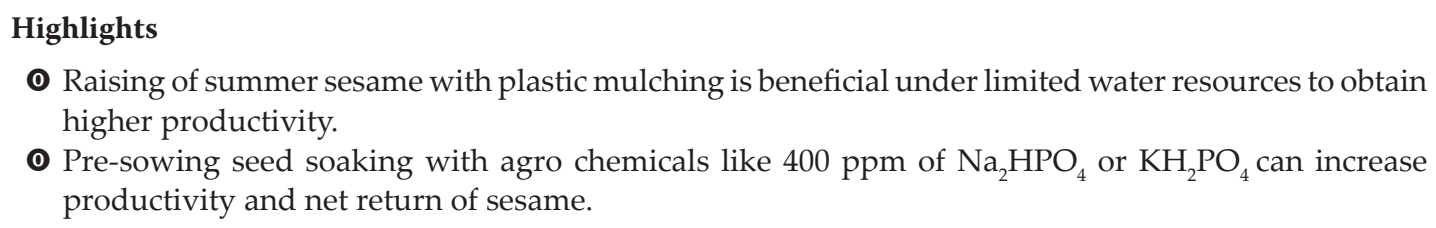

Keywords: Sesame, mulching, paddy straw, plastic; seed-soaking, agro chemicals, growth, yield, economics

Sesame (Sesamum indicum L.) is an important oil seed crop of the world belonging to the family Pedaliaceae. It is generally a photosensitive crop. Sesame is a versatile crop having diversified usage and contains $48-52 \%$ oil, $20-25 \%$ protein and $14-$ $20 \%$ carbohydrate. Sesame seed has pronounced antioxidant activity and thereby offer higher shelflife and is called as 'seeds of immortality'. The oil 
is used for cooking, baking, candy making, soaps, lubricant, hair treatment, paint, perfumery products, industrial uses, drugs and alternative medicine in the control of blood pressure, stress and tension (Oyeogbe et al. 2015; Chauhan et al. 2017). The oil is also used in the manufacture of soaps, paints, perfumes, pharmaceuticals and insecticides. Sesame cake, left after oil extraction, is an excellent high protein (30-50\%) food for poultry and livestock (Oplinger et al. 1997). India accounts for the production of 8.28 lakh tonnes from 17.46 lakh ha area with $474 \mathrm{~kg} /$ ha productivity of sesamum during 2014-15. The area and production of sesamum are higher in kharif season while, productivity is higher in summer season (Kumar et al. 2017). This evidently indicates the potentiality for improvement in yield. Actually summer sesame faces abiotic stresses like insufficient soil moisture, air temperature along with faulty agronomic management and balanced nutrient management, water management and other agronomic measures can be adopted to maximize the productivity (Mondal et al. 1997). In Odisha sesame occupies 0.23 lakh hectare area with a production of 0.55 lakh tons but the productivity of sesame in Odisha is very low ( $237 \mathrm{~kg} \mathrm{ha}^{-1}$ ) as compared to many other states like West Bengal (951 kg ha-1), Assam (746 kg ha-1) and Tamil Nadu (621 kg ha-1). There is ample scope to increase its productivity by means of improving the cultivation techniques. Under limited water conditions for raising of summer sesame, mulching can play a vital role to obtain potential yield. Further, pre-sowing seed soaking with agro chemicals is known to enhance growth and productivity of crops. Considering the above, a study was conducted to test the efficiency of pre-sowing seed treatment by agrochemicals and mulching on productivity of sesame.

\section{MATERIALS AND METHODS}

The experiment was conducted at Bagusala Farm of MS Swaminathan School of Agriculture, Centurion University of Technology and Management, Paralakhemundi, Odisha (located at the $18^{0} 77^{\prime} \mathrm{N}$ latitude and $84^{\circ} 09^{\prime} \mathrm{E}$ longitudes, at an elevation of $61 \mathrm{~m}$ above mean sea level) during summer season of 2018. The soil was sandy loam in texture having moderate water holding capacity with a $\mathrm{pH}$ of $6.1,0.73 \%$ organic carbon and 230, 32.1 and 346 $\mathrm{kg} \mathrm{ha}^{-1}$ of available $\mathrm{N}, \mathrm{P}$ and $\mathrm{K}$, respectively. The experiment was laid out in Split Plot Design (SPD), with two factors, namely, mulching (main plot) and seed soaking with agro-chemicals (sub-plot). In main plot three treatments of mulching were taken, namely, $\mathrm{M}_{0^{\prime}}$ no mulching, $\mathrm{M}_{1^{\prime}}$ paddy straw mulching and $\mathrm{M}_{2}$, plastic mulching, however, four seed soaking treatments, viz., $\mathrm{P}_{1^{\prime}}$ water soaked, $\mathrm{P}_{2^{\prime}}$ 200 ppm potassium chloride (KCL), $\mathrm{P}_{3^{\prime}} 400$ ppm potassium dihydrogen phosphate $\left(\mathrm{KH}_{2} \mathrm{PO}_{4}\right)$ and $\mathrm{P}_{4^{\prime}}$ 400 ppm disodium hydrogen phosphate $\left(\mathrm{Na}_{2} \mathrm{HPO}_{4}\right)$ were considered in sub-plot. Thus 12 treatments combinations were replicated thrice in $4 \mathrm{~m} \times 3 \mathrm{~m}$ plots. A fertilizer dose of $30 \mathrm{~kg} \mathrm{~N}, 20 \mathrm{~kg}$ P2O5 and $20 \mathrm{~kg} \mathrm{~K}_{2} \mathrm{O} \mathrm{ha}^{-1}$ was applied as basal dose at the time of final land preparation along with $10 \mathrm{t}$.

\section{Effect of mulching on growth and productivity}

From the results it is clearly observed that mulching had a great influence on growth and well decomposed FYM ha-1. The seeds were sown in lines $30 \mathrm{~cm}$ apart after three days of final land preparation in the first week of February, 2018 at a depth of $3-4 \mathrm{~cm}$. The crop received a total rainfall $12.73 \mathrm{~cm}$ during the period of experimentation. Observations on growth parameters, yield attributing traits, seed and stick yields of sesame were recorded and analysed statistically (Panse and Sukhatme 1985).

\section{RESULTS AND DISCUSSION}

Productivity of sesame. Plant height recorded at 90 days after sowing (DAS) revealed that mulching expressed its influence in enhancement of the growth character and the maximum plant height was recorded with plastic mulching $\left(\mathrm{M}_{2}\right)$ which was further significantly superior to paddy straw mulching $\left(\mathrm{M}_{1}\right)$ and no mulching $\left(\mathrm{M}_{0}\right)$. Moreover, paddy straw mulching $\left(\mathrm{M}_{1}\right)$ significantly increased plant height over the treatment no mulching $\left(\mathrm{M}_{0}\right)$. In case of dry matter accumulation at 90 DAS, the treatment plastic mulching $\left(\mathrm{M}_{2}\right)$ resulted in significantly more dry matter production than paddy straw mulching and no mulching. The treatment no mulching $\left(\mathrm{M}_{0}\right)$ was further significantly inferior to paddy straw mulching at 90 DAS.

Mulching had significant influence on the number of capsule plant ${ }^{-1}$ of sesame (Table 1). Plastic mulching i.e., $\mathrm{M}_{2}$ recorded the maximum number of capsule plant ${ }^{-1}(37.10)$ followed by paddy straw mulching, i.e., $\mathrm{M}_{1}$ and it was found that 
Table 1: Effect of mulching and pre-sowing seed treatment on growth parameters and yield attributes of sesame

\begin{tabular}{|c|c|c|c|c|c|c|c|}
\hline \multirow[b]{2}{*}{ Treatments } & \multicolumn{2}{|c|}{ Growth Parameters } & \multicolumn{5}{|c|}{ Yield attributing characters } \\
\hline & $\begin{array}{c}\text { Plant height } \\
\text { at harvest } \\
(\mathrm{cm})\end{array}$ & $\begin{array}{l}\text { Dry matter } \\
\text { accumulation } \\
\text { at harvest } \\
\left(\mathrm{gm}^{-2}\right)\end{array}$ & $\begin{array}{c}\text { Number } \\
\text { of capsule } \\
\text { plant }^{-1}\end{array}$ & $\begin{array}{l}\text { Number } \\
\text { of seeds } \\
\text { capsule }^{-1}\end{array}$ & $\begin{array}{c}\text { Number } \\
\text { of seeds } \\
\text { plant }^{-1}\end{array}$ & $\begin{array}{c}\text { Seed } \\
\text { weight per } \\
\text { plant (g) }\end{array}$ & $\begin{array}{l}1000 \text { seeds } \\
\text { weight }(\mathrm{g})\end{array}$ \\
\hline \multicolumn{8}{|l|}{ Mulching } \\
\hline No mulching & 57.25 & 221.48 & 32.08 & 70.75 & 2265.64 & 5.15 & 2.62 \\
\hline Plastic mulching & 65.73 & 279.10 & 37.10 & 79.58 & 2961.35 & 7.84 & 2.78 \\
\hline S. Em. $(( \pm)$ & 0.38 & 0.36 & 0.22 & 0.36 & 32.74 & 0.07 & 0.01 \\
\hline C.D. $(P=0.05)$ & 1.51 & 1.44 & 0.89 & 1.44 & 128.58 & 0.31 & NS \\
\hline C.V. $(\%)$ & 7.5 & 7.9 & 7.9 & 5.9 & 14.9 & 14.6 & 13.2 \\
\hline \multicolumn{8}{|c|}{ Seed soaking with agro-chemicals } \\
\hline $\begin{array}{l}\text { Seed soaking with } 400 \text { ppm } \\
\mathrm{KH}_{2} \mathrm{PO}_{4}\end{array}$ & 47.08 & 193.34 & 27.22 & 57.25 & 2015.30 & 5.39 & 2.05 \\
\hline $\begin{array}{l}\text { Seed soaking with } 400 \text { ppm } \\
\mathrm{Na}_{2} \mathrm{HPO}_{4}\end{array}$ & 52.10 & 197.33 & 27.61 & 58.50 & 2225.13 & 5.69 & 2.07 \\
\hline S. Em. $(( \pm)$ & 0.57 & 2.02 & 0.40 & 0.51 & 22.22 & 0.10 & 0.04 \\
\hline C.D. $(P=0.05)$ & 1.70 & 6.03 & 1.20 & 1.52 & 66.03 & 0.32 & NS \\
\hline C.V. $(\%)$ & 8.46 & 7.34 & 10.45 & 6.17 & 7.60 & 14.97 & 13.6 \\
\hline $\mathrm{M} \times \mathrm{P}($ Interaction $)$ & NS & NS & NS & NS & NS & NS & NS \\
\hline
\end{tabular}

$M_{2}$ treatment significantly differed from other treatments. No mulching treatment i.e., $\mathrm{M}_{0}$ produced the lowest number of capsule plant ${ }^{-1}$ (32.08) during the experimentation. The percentage increase of number of capsule plant ${ }^{-1}$ of $\mathrm{M}_{2}$ over $\mathrm{M}_{1}$ and $\mathrm{M}_{0}$ was 5.36 and $15.64 \%$, respectively. Maximum number of seeds capsule ${ }^{-1}(79.58)$ was also recorded under plastic mulching i.e., $\mathrm{M}_{2}$ followed by paddy straw mulching i.e., $M_{1}$. Plastic mulching i.e., $M_{2}$ did not show any significant effect on seeds capsule ${ }^{-1}$ of sesame. Greater seeds plant ${ }^{-1}$ values were recorded under plastic mulching i.e., $\mathrm{M}_{2}$ followed by paddy straw mulching i.e., $\mathrm{M}_{1}$. The values of seeds plant ${ }^{-1}$ by $M_{2}$ and $M_{1}$ were 2961.35 and 2394.65 , respectively. The lowest seeds plant ${ }^{-1}$ was observed under no mulching i.e., $M_{0}$. Treatment $M_{2}$ had differed significantly with all other treatments on seeds plant ${ }^{-1}$ of sesame. Mulching significantly influenced the seed weight plant ${ }^{-1}$. Highest values of seeds weight plant $^{-1}(7.84 \mathrm{~g})$ was recorded by plastic mulching i.e., $\mathrm{M}_{2}$ and differed significantly from other mulching treatments. The lowest seeds weight plant ${ }^{-1}$ was observed under no mulching i.e., $\mathrm{M}_{0}$. The highest 1000 seed weight (2.78 g) was recorded by plastic mulching i.e., $\mathrm{M}_{2}$ followed by paddy straw mulching i.e., $\mathrm{M}_{1}$.

Mulching had significant influence on the seed yield $\left(\mathrm{kg} \mathrm{ha}^{-1}\right)$ of sesame. The maximum seed yield (1321.87 $\mathrm{kg} \mathrm{ha}^{-1}$ ) was recorded under plastic mulching i.e., $\mathrm{M}_{2}$ which was significantly more than other mulching treatments. The lowest seed yield (1085.93 $\mathrm{kg} \mathrm{ha}^{-1}$ ) was recorded under no mulching i.e., $\mathrm{M}_{0}$ treatment. The percentage increase in seed yield under $M_{2}$ over $M_{1}$ and $M_{0}$ were 15.10 and $21.72 \%$, respectively. The stick yield of sesame was also influenced by mulching and similar trend was observed as noted in case of seed yield. Higher seed yield in case of plastic mulching i.e., $\mathrm{M}_{2}$ treatment might be due to the fact that the crop received better water due to maintenance of soil temperature, minimizing evaporation and weed growth by plastic mulching throughout the growth period which remarkably stimulated the yield attributing characters (Wenguang et al. 1995; Maitra and Samui 2000). Proper moisture in the root zone has helped in translocation of nutrients as well as maintenance of 
proper functioning of biochemical reaction resulting in higher growth and productivity. Another reason might be due to greater dry matter production eventually partitioned to the growth attributing characters which in turn produced maximum seed yield. Plastic mulching recorded higher seed yield $\left(\mathrm{kg} \mathrm{ha}^{-1}\right)$ as compared to paddy straw mulching, as reported by Mandal et al. (2012).

\section{Effect of pre-sowing seed soaking on growth and productivity}

Pre-sowing seed soaking with agro-chemicals showed influence on growth of summer sesame (Table 1). The treatment $\mathrm{P}_{4^{\prime}}$ that is, seed soaking with 400 ppm disodium hydrogen phosphate $\left(\mathrm{Na}_{2} \mathrm{HPO}_{4}\right)$ resulted in maximum height of the plant and it produced significantly more plant height than other treatments. Further, the treatment $\mathrm{P}_{3}$, i.e., seed soaking with 400 ppm potassium dihydrogen phosphate $\left(\mathrm{KH}_{2} \mathrm{PO}_{4}\right)$ exhibited taller plants than $\mathrm{P}_{2}$ (seed soaking with 200 ppm KCL) and $P_{1}$ (water soaking). Moreover, $\mathrm{P}_{2}$ (seed soaking with 200 ppm KCL) was significantly superior to $P_{1}$ (water soaking). Enhancement in height in plant obtained under seed soaking treatments was probably due to embryo enlargement, advanced germination (Austin et al. 1969; Hegarty 1070) and better preservation of cellular ultra-structure with an elasticity and viscosity of protoplasm (Henckel 1964). Dry matter accumulation of sesame was influenced by presowing seed soaking treatment. The treatment $\mathrm{P}_{4}$ (seed soaking with 400 ppm $\mathrm{Na}_{2} \mathrm{HPO}_{4}$ ) being statistically at par with $\mathrm{P}_{3}$ (seed soaking with 400 ppm $\mathrm{KH}_{2} \mathrm{PO}_{4}$ ) produced significantly more dry matter than $\mathrm{P}_{2}$ (seed soaking with 200 ppm $\mathrm{KCL}$ ) and $\mathrm{P}_{1}$ (water soaking). Besides, $\mathrm{P}_{2}$ (seed soaking with $200 \mathrm{ppm} \mathrm{KCL}$ ) and $\mathrm{P}_{1}$ (water soaking) remained statistically at par in production of dry matter. Seed soaking in water or growth regulating agro-chemicals might be responsible for increased dry matter production by enhancing mitochondrial activity, DNA, RNA and protein synthesis (Henckel 1964) and lipid peroxidation (Berjack 1978).

The maximum number of capsule plant $\mathrm{t}^{-1}$ of sesame was obtained by application of 400 ppm $\mathrm{Na}_{2} \mathrm{HPO}_{4^{\prime}}$ i.e., $\mathrm{P}_{4}$ and it was statistically at par with application of 400 ppm $\mathrm{KH}_{2} \mathrm{PO}_{4}$, i.e., $\mathrm{P}_{3}$. The number of seeds capsule $^{-1}$ was significantly influenced by the application of different agro chemicals and the maximum number of seeds capsule ${ }^{-1}$ of sesame (58.50) was recorded under application of 400 ppm $\mathrm{Na}_{2} \mathrm{HPO}_{4}$, i.e., $\mathrm{P}_{4}$. The maximum seeds plant ${ }^{-1}$ (2966.84) was obtained by seed soaking with 400 ppm $\mathrm{Na}_{2} \mathrm{HPO}_{4}$, i.e., $\mathrm{P}_{4}$ and was followed by seed soaking with $400 \mathrm{ppm} \mathrm{KH}_{2} \mathrm{PO}_{4}$, i.e., $\mathrm{P}_{3}$. Further, seed weight plant $^{-1}(\mathrm{~g})$ of sesame was significantly influenced by pre-sowing seed treatment with agro chemicals. Highest seeds weight plant $^{-1}(5.69 \mathrm{~g})$ was obtained by seed soaking with 400 ppm $\mathrm{Na}_{2} \mathrm{HPO}_{4}$ i.e., $\mathrm{P}_{4}$ and it was followed by seed soaking with 400 ppm $\mathrm{KH}_{2} \mathrm{PO}_{4}$, i.e., $\mathrm{P}_{3}$. The treatment $\mathrm{P}_{4}$ had differed significantly with all other treatments. Pre sowing seed treatment with agro chemicals did not show any significant influence on 1000 seeds weight of sesame. The maximum values of 1000 seeds weight ( $2.07 \mathrm{~g})$ was obtained by seed soaking with $400 \mathrm{ppm}$ Disodium hydrogen phosphate $\left(\mathrm{Na}_{2} \mathrm{HPO}_{4}\right)$, i.e., $\mathrm{P}_{4}$ followed by seed soaking with 400 ppm Potassium dihydrogen phosphate $\left(\mathrm{KH}_{2} \mathrm{PO}_{4}\right)$, i.e., $\mathrm{P}_{3}$. The lowest 1000 seeds weight (1.96 g) was obtained by water soaking i.e., $\mathrm{P}_{1}$.

Table 2: Effect of mulching and pre-sowing seed treatment with agro-chemicals on seed and stick yield of sesame

\begin{tabular}{|c|c|c|}
\hline \multirow[b]{2}{*}{ Treatments } & \multicolumn{2}{|c|}{ Yield (kg ha-1) } \\
\hline & $\begin{array}{c}\text { Seed yield } \\
\left(\mathrm{kg} \mathrm{ha}^{-1}\right)\end{array}$ & $\begin{array}{c}\text { Stick yield } \\
\left(\mathrm{kg} \mathrm{ha}^{-1}\right)\end{array}$ \\
\hline \multicolumn{3}{|l|}{ Mulching } \\
\hline No mulching & 1085 & 1780 \\
\hline Paddy straw mulching & 1148 & 2003 \\
\hline Plastic mulching & 1321 & 2262 \\
\hline S. Em. ( ( \pm$)$ & 8.45 & 8.57 \\
\hline C.D. $(P=0.05)$ & 33.18 & 33.68 \\
\hline C.V. $(\%)$ & 8.5 & 5.1 \\
\hline \multicolumn{3}{|c|}{ Seed treatment with agro-chemicals } \\
\hline Water soaked & 829 & 1423 \\
\hline Seed soaking with 200 & & \\
\hline ppm KCL & 867 & 1460 \\
\hline $\begin{array}{l}\text { Seed soaking with } 400 \\
\text { ppm } \mathrm{KH}_{2} \mathrm{PO}_{4} \\
\text { Seed soaking with } 400\end{array}$ & 918 & 1565 \\
\hline $\mathrm{ppm} \mathrm{Na}_{2} \mathrm{HPO}_{4}$ & 940 & 1597 \\
\hline S. Em. $( \pm)$ & 10.48 & 19.68 \\
\hline C.D. $(P=0.05)$ & 33.14 & 58.48 \\
\hline C.V. $(\%)$ & 8.0 & 8.8 \\
\hline $\mathrm{M} \times \mathrm{P}$ (Interaction) & NS & NS \\
\hline
\end{tabular}

During the period of experimentation, pre sowing seed treatment with 400 ppm Disodium hydrogen 
phosphate $\left(\mathrm{Na}_{2} \mathrm{HPO}_{4}\right)$, i.e., $\mathrm{P}_{4}$ gave highest seed yield $\left(940.62 \mathrm{~kg} \mathrm{ha}^{-1}\right)$ followed by seed treatment with 400 ppm Potassium dihydrogen phosphate $\left(\mathrm{KH}_{2} \mathrm{PO}_{4}\right)$, i.e., $\mathrm{P}_{3}$ (Table 2). Treatment $\mathrm{P}_{4}$ i.e., pre sowing seed treatment with 400 ppm Disodium hydrogen phosphate $\left(\mathrm{Na}_{2} \mathrm{HPO}_{4}\right)$ had differed significantly with all other treatments. The percentage increase of $\mathrm{P}_{4}$ over $\mathrm{P}_{3}, \mathrm{P}_{2}$ and $\mathrm{P}_{1}$ were about $2.38 \%, 8.46 \%$ and $13.37 \%$ of seed yield of sesame, respectively. Further, pre sowing seed treatment with 400 ppm Disodium hydrogen phosphate $\left(\mathrm{Na}_{2} \mathrm{HPO}_{4}\right)$, i.e., $\mathrm{P}_{4}$ gave highest stick yield (1597.08 $\left.\mathrm{kg} \mathrm{ha}^{-1}\right)$, while seed treatment with 400 ppm Potassium dihydrogen phosphate $\left(\mathrm{KH}_{2} \mathrm{PO}_{4}\right)$ i.e., $\mathrm{P}_{3}$ recorded stick yield of $1565.83 \mathrm{~kg} \mathrm{ha}^{-1}$. Treatment $\mathrm{P}_{4}$, i.e., pre sowing seed treatment with 400 ppm Disodium hydrogen phosphate $\left(\mathrm{Na}_{2} \mathrm{HPO}_{4}\right)$ differed significantly over all other treatments on stick yield of sesame. Whereas treatment $\mathrm{P}_{2}$, i.e., seed treatment with 200 ppm KCL was statistically at par with treatment $\mathrm{P}_{1}$ i.e., seed treatment by water soaking. The percentage increase of $\mathrm{P}_{4}$ over $\mathrm{P}_{3}, \mathrm{P}_{2}$ and $\mathrm{P}_{1}$ were about $1.99 \%, 9.35 \%$ and $15.88 \%$ of stick yield of sesame, respectively. In sesame, enhancement of growth obtained by seed soaking with agro-chemicals influenced yield attributes and proper translocation of assimilate to sink increased seed yield of sesame. Influence of agrochemicals in promotion of crop growth and productivity was earlier observed by the researchers (Maitra et al. 1997, Maitra et al. 1998; Mandal et al. 2012). Moreover, in the study, non-significant impact between mulching and pre-sowing seed soaking with agro-chemicals was noted in terms of growth parameters, yield attributes, seed and stick yield of sesame.

\section{Economics}

The economics of sesame cultivation as affected by mulching and pre-sowing seed soaking was calculated for all treatment combinations and presented in table 3 . The maximum cost of production ( $₹ 39,255 \mathrm{ha}^{-1}$ ) was recorded by $\mathrm{M}_{2} \mathrm{P}_{3^{\prime}}$ i.e., plastic mulching with seed soaking in 400 ppm potassium dihydrogen phosphate $\left(\mathrm{KH}_{2} \mathrm{PO}_{4}\right)$ followed by $\mathrm{M}_{2} \mathrm{P}_{4}$, i.e., plastic mulching with $400 \mathrm{ppm}$ disodium hydrogen phosphate $\left(\mathrm{Na}_{2} \mathrm{HPO}_{4}\right)$. Highest gross return of ( $₹ 1,00,625 \mathrm{ha}^{-1}$ ) was recorded by $\mathrm{M}_{2} \mathrm{P}_{4}$, i.e., plastic mulching with 400 ppm disodium hydrogen phosphate $\left(\mathrm{Na}_{2} \mathrm{HPO}_{4}\right)$ and the lowest gross return (₹ 73,937.5 ha-1 $)$ was recorded by $\mathrm{M}_{0} \mathrm{P}_{0^{\prime}}$ i.e., no mulching with water soaking. Maximum net return of (₹ $61,403.2 \mathrm{ha}^{-1}$ ) of sesame was recorded by $\mathrm{M}_{2} \mathrm{P}_{4}$, i.e., plastic mulching with 400 ppm disodium hydrogen phosphate $\left(\mathrm{Na}_{2} \mathrm{HPO}_{4}\right)$, whereas the lowest net return (₹ $48717.5 \mathrm{ha}^{-1}$ ) was recorded by $\mathrm{M}_{0} \mathrm{P}_{0}$, i.e. no mulching with water soaking. The benefit: cost ratio clearly indicated that the highest value (2.12) was recorded by treatment $\mathrm{M}_{0} \mathrm{P}_{4^{\prime}}$ i.e. no mulching with 400 ppm disodium hydrogen phosphate $\left(\mathrm{Na}_{2} \mathrm{HPO}_{4}\right)$ and the lowest cost: benefit ratio (0.95) was recorded by $\mathrm{M}_{1} \mathrm{P}_{1}$, i.e. paddy straw mulching with water soaking.

Table 3: Economics of sesame cultivation as affected by mulching and pre-sowing seed soaking treatments

\begin{tabular}{|c|c|c|c|c|}
\hline Treatments & $\begin{array}{c}\text { Cost of } \\
\text { cultivation } \\
\left(₹ h^{-1}\right)\end{array}$ & $\begin{array}{l}\text { Gross return } \\
\qquad\left(₹ h^{-1}\right)\end{array}$ & $\begin{array}{l}\text { Net return } \\
\left(₹ h^{-1}\right)\end{array}$ & $\begin{array}{l}\text { Benefit: } \\
\text { cost Ratio }\end{array}$ \\
\hline No mulching, seed soaking with 200 ppm KCL & 25220.5 & 74812.5 & 49592 & 1.96 \\
\hline No mulching, seed soaking with 400 ppm $\mathrm{KH}_{2} \mathrm{PO}_{4}$ & 25275 & 76562.5 & 51287.5 & 2.03 \\
\hline Paddy straw mulching, seed soaking with 200 ppm KCL & 38720.5 & 79625 & 40904.5 & 1.05 \\
\hline Paddy straw mulching, seed soaking with 400 ppm $\mathrm{KH}_{2} \mathrm{PO}_{4}$ & 38775 & 82250 & 43475 & 1.12 \\
\hline Paddy straw mulching, seed soaking with 400 ppm $\mathrm{Na}_{2} \mathrm{HPO}_{4}$ & 38741.8 & 84000 & 45258.2 & 1.16 \\
\hline Plastic mulching, seed soaking with water & 39200 & 82687.5 & 43487.5 & 1.11 \\
\hline
\end{tabular}




\section{CONCLUSION}

The results of the field experiment conclude that summer sesame may be cultivated in south Odisha conditions with plastic mulching and pre-sowing seed soaking with either of 400 ppm of $\mathrm{Na}_{2} \mathrm{HPO}_{4}$ or 400 ppm of $\mathrm{KH}_{2} \mathrm{PO}_{4}$ to obtain higher productivity and more return.

\section{ACKNOWLEDGEMENTS}

The authors are grateful to the authority of M.S. Swaminathan School of Agriculture, Centurion University of Technology and Management for funding and necessary support to carry out the experiment.

\section{DECLARATION}

The content is based on the research work carried out by the first author for partial fulfilment of M.Sc. Ag. (Agronomy) degree and there is no conflict of interest among the authors.

\section{REFERENCES}

Chauhan, G.V., Pyare, R., Verma, V.K., Trivedi, V.K. and Tomar, R. 2017. Studies on the Productivity, Profitability and Quality of Sesame Based Intercropping with Kharif Crops under Different Weed Management Practices, International Journal of Applied and Pure Science and Agriculture, 3(7): 51-55

Kumar, D., Ardeshna, R.B., Patel A.K. and Singh, N. 2017. Economic assessment and biological feasibility of summer sesamum based intercropping systems, International Journal of Agricultural Sciences, 7(7): 1332-1337.
FAOSTAT, 2012. Sesame yield and productivity http://faostat3. fao.org/compare/E. 2012. Accessed Feb. 24, 2018.//

Maitra, S., Ghosh, D.C., Sounda, G., Jana, P.K. and Roy, D.K. 1998. Effect of seed treatment on growth and productivity of finger millet under rained lateritic belt of West Bengal. Indian Agriculturist, 42(1): 37- 43.

Maitra, S. and Samui, S.K. 2000. Effect of polyethylene mulching on growth and productivity of groundnut (Arachis hypogaea L.) in Sundarbans. Green Technology, 3: 38-41.

Maitra, S., Sounda, S., Ghosh, D.C. and Jana, P.K. 1997. Effect of seed treatment on Finger millet (Eleusine coracana) varieties in rainfed upland. Indian Journal of Agricultural Sciences. 67(10): 478-480.

Mandal, T.K., Puste, A.M., Pramanik, K. and Ray, K. 2012. Effect of mulching and pre-sowing seed treatment with agro-chemicals on the growth and yield of sesame (Sesamum indicum L.) under rainfed situation. Journal of Interacademicia, 16(3): 626-629.

Mondal, D.K., Sounda, G., Maitra, S. and Roy, D.K. 1998. Effect of sowing dates and levels of irrigation on growth, productivity, oil yield and water use of summer sesame (Sesamum indicum L), Indian Agriculturist, 41(1): 15-21.

Oplinger, E.S., Putnam, D.H., Kaminski, A.R., Hanson, C.V., Oeike, E.A., Schulte, E.E and Doll, J.D. 1997. Sesame. In: Alternative Field Crops Manual, University of Wisconstin, USA. Cf. www.hort.purdue.edu/newcrop.

Oyeogbe, A.I., Vaghela, S. and Patel, B. 2015. Economics of Sustainable Intensification and Diversification of Sesamebased Cropping Systems in North Gujarat India, American Journal of Agricultural Science, 2(3): 85-90.

Panse, V.G. and Sukhatme, P.V. 1985. Statistical methods for Agricultural workers, ICAR, New Delhi.

Wenguang, H., Shufen, D. and Qingwei, S. 1995. High yield technology for groundnut. Arachis Newsletter, 15: 1-22. 